\title{
Microcontroller Systems in Education for Sustainable Development Service. A Qualitative Thematic Meta-Analysis
}

\author{
Maria Savelidi, Socrates Savelides, Efthymios Georgousis, Georgia Papadopoulou, \\ Rigo Fasouraki, and Hara Drinia
}

\begin{abstract}
Goal of the present paper is to answer the research question: Can the proper use of Microcontroller Board Systems as educational tools help achieve the goals of Education for Sustainable Development? In order to answer the aforementioned question, a meta-analysis of the qualitative strategy of four recently published relevant papers was utilized. The technique of Thematic Analysis was used. The results show that the proper adaptation of Microcontroller Board Systems in the educational process can adequately help achieve the goals of the Education for Sustainable Development. In order to achieve these goals in the pedagogical framework, the Microcontroller System can be adapted in such a way as to serve the approaches of holistic \& systemic thinking, HASS\&STEM interdisciplinarity and multidisciplinarity, constructivist approach to knowledge, cooperative learning, critical thinking, cultivation of values, and learning satisfaction of the Education for Sustainable Development.
\end{abstract}

Keywords - Education for Sustainable Development (ESD), meta-survey, Microcontroller board system, Qualitative thematic meta-analysis.

\section{INTRODUCTION}

\section{A. Theoretical Framework}

The present paper explores the possibility of utilizing systems based on Microcontrollers as educational tools in environmental education and, in general, in Education for Sustainable Development (ESD). The Microcontroller Board is a system that can serve as the basis for the composition of "intelligent" electromechanical mechanisms (electronic, electric, and mechanical components), that can be programmed, and, in general, controlled by the system. It

Submitted on November 4, 2021.

Published on February 16, 2022.

Maria Savelidi, Faculty of Business and Economics, MSc Business

Engineering, Finance, University of Ghent, Belgium.

(e-mail: maria.savelidi@ugent.be)

Socrates Savelides, University of Thessaly, Greece.

(e-mail: ssavelidis@uth.gr)

Efthymios Georgousis, Department of Geology and Geoenvironment,

National and Kapodistrian University of Athens, Greece.

(e-mail: egeorgousis@ geol.uoa.gr)

Georgia Papadopoulou, University of Thessaly, Greece.

(e-mail: georgpapadopoulou ${ }^{\circledR}$ uth.gr)

Rigo Fasouraki, Hellenic Ministry of Education and Religious Affairs,

Greece.

(e-mail: rigofasou@gmail.com)

Hara Drinia, Department of Geology and Geoenvironment, National and

Kapodistrian University of Athens, Greece.

(e-mail: cntrinia@geol.uoa.gr) is an easy-to-use, and simple system that can be used also for educational purposes [1]. An important element is the system's framing by web software (e.g., Tinkercad ${ }^{\mathrm{TM}}$ ), which can simulate an actual system's application, from the stage of electromechanical composition, until the stage of programming and control, no matter if the application is indeed performed or not [2]. It is an open-source platform that is based on simple materials and software, it is an easy tool for quick standardization, that also address users without a background in electronics and programming, such as students of primary [3] and secondary education [1], [4] The systems, with the help of relevant software, can read data from inputs such as sensors, keys, internet input, and transform them into output, such as engine activation, LED activation, internet publication, etc. [5]. The Microcontroller Board Systems were the "brain" of thousands of projects, from everyday objects to complex professional and educational robots (Microcontroller Board, n.d.) The applications of the Microcontroller seem to be sources of data of environmental interest, since they can include sensors for detecting gaseous pollutants, microparticles of the atmosphere, radiation, and climatic characteristics such as temperature, humidity, pressure, etc. [4]. These data sources can update computer systems, even smartphones [6]-[7]. Finally, the software interface by which they are controlled, can manage the data by outputting relevant information that can be utilized, or by controlling robotic mechanisms that can also be of use, by performing actions of environmental impact [5].

\section{B. Goal \& Research Question}

In this way, the present research aims at exploring fields of utilizing Microcontroller Board Systems in ESD based on relevant research articles and applications of said systems. In particular, the goal of the present research is the answer to the following question:

Can the proper use of Microcontroller Board |Systems as educational tools help achieve the goals of Education for Sustainable Development?

To answer this question, the following process is utilized: Firstly, recently published relevant papers are researched, which refer to the application of Microcontroller Board Systems in environmental education and, in general, in ESD. With particular emphasis in the results, discussion, and conclusions, the original texts of the papers are qualitatively analyzed based on the technique of Thematic Analysis (ThA). Attempts are made to identify conceptual patterns that refer to the educational process developed in each paper and are consistent with seven approaches that are considered 
necessary for the development of educational frameworks for ESD. The seven approaches are the ThA Categories. The patterns are classified in these categories, are examined qualitatively, and the answer to this research question is extracted.

\section{Conceptual Definitions}

\section{1) Contextual Learning}

It is based on a constructivist teaching and learning approach, by which people learn by building meaning through experiential methods, interpretation, and interaction with their environment [8] as cited in [5].

\section{2) Computational Thinking}

It is a field of techniques that approaches problem solving, the design of systems that help solve complex problems faced by people, and the understanding of human behavior based on fundamental concepts of information technology [9]-[10].

\section{3) Discovery learning}

It is a teaching method in which students act with the aim of discovering knowledge under the guidance of the teacher and is considered to develop students' research skills and contribute to their success more than traditional teaching processes and techniques [11].

\section{4) Learning Satisfaction}

Regarding the concept of Learning Satisfaction, [12] mention that students' learning satisfaction of their school learning plays an important role. [It is] ... an index to evaluate students' learning results and it is also one of the most important indicators of teaching quality. Knowledge, skills, attitude, capabilities and emotion are all involved in the delivery of education, and they are also basic factors affecting learning results.

\section{Educational Framework of Education for Sustainable Development}

Education for Sustainable Development (ESD)...empowers learners to make informed decisions and take responsible actions for environmental integrity, economic viability, and a just society, for present and future generations, while ensuring respect for cultural diversity [13] as cited in [14].

Achieving the goals of Education for Sustainable Development (ESD) can take place within a pedagogical framework that is required to be characterized by six educational or pedagogical approaches [15] as cited in [16]: These are holistic \& systemic thinking, HASS\&STEM interdisciplinarity \& multidisciplinarity, constructivist approach to knowledge, cooperative learning, critical thinking, cultivation of values.

\section{1) Holistic \& systemic thinking}

The holistic character of ESD supports a holistic approach to learning, combines fields of knowledge and experience related to humanity, arts, social, spiritual, science, technology, engineering, mathematics and mobilizes the development of the individual also holistically (morally, cognitively, socially, emotionally, and in a psychomotor aspect) [17]-[18]. Also, this holistic character of ESD concerns the recognition, interaction, and interconnection of all educational and pedagogical dimensions such as the curriculum and the projected values [17]-[18]. The systemic theory in the field of ESD, takes the form of a simplified methodological approach of environmental situations and is referred to as systemic approach [19]. The notion that the environment should be considered as a whole is also adopted by international conferences on environmental education in the 1970s. At the Tbilisi Conference, for example, it is emphasized that the environment is a systemic reality [20]. Systemic thinking is, at the same time, analytical and synthetic, it moves from the individual parts to the whole, from structure to process, it focuses on relationships, interactions, connections and the frame of reference, and can contribute to this direction [21].

\section{2) HASS\&STEM Interdisciplinarity \& multidisciplinarity}

The interdisciplinary and multidisciplinary models are the two main ways of integrating ESD in school. In the context of the interdisciplinary model, ESD is fed with concepts and approaches from the individual school subjects (courses), while in the context of the multidisciplinary model, the elements of ESD are sought to be integrated in the existing courses and to permeate the curricula [22]-[23]. The widespread interdisciplinary and systemic nature of environmental issues requires new forms of approach to shaping the content and structure of the ESD curriculum. Thus, we inevitably move to the concept of cross-thematic educational approach [24], which is a transfer of interdisciplinarity in school practice, in the direction of knowledge integration. However, the concept of interdisciplinarity is subject to various interpretations and is usually limited to a selection of activities from certain subjects accompanied by a relaxed teaching methodology. That is why the adoption by environmental education of the STEM methodology (Science, Technology, Engineering, Mathematics), which gives importance to teaching methods, contributes to the creative involvement of students in the search, discovery, and invention of solutions to problems. However, STEM's focus on certain subjects is very static and its disciplines should focus on a set of practices and processes, in order for special knowledge and learning to emerge. They need to be merged with concepts and values, which requires collaboration and interdisciplinary efforts with the Humanities, Arts and Social Sciences (HASS) disciplines. The benefit of switching from STEM objects to HASS objects is important because it allows ideas and problems to be approached from different perspectives [25][26]. In the Greek educational reality, the results from the implementation of an educational scenario of experimental interdisciplinary didactic management of educational objects of the STEM and HASS branches with the support of ICTs, prove that it is possible to design and implement didactic approaches that combine the interdisciplinary subjects of the two branches [27].

\section{3) Constructivist approach to knowledge}

Costructivism, one of the basic theories of learning, argues that the intellect is a function of constructing meanings based on the experience of the individual [28]. The construction of knowledge therefore takes place based on pre-existing experiences, mental constructs, beliefs, and "theories" that each person uses in order to interpret objects 
or events [29]. Reference [30], by expressing the principles of constructivism, argues that learning takes place by correlating, integrating, and assimilating new concepts into existing propositional networks and the broader cognitive structures of the learner.

\section{4) Cooperative learning}

The fundamental elements that constitute collaborative learning are positive interdependence, interaction, individual and group responsibility, social skills, team self-assessment [31]. The value and necessity of cooperation at local, national and international level to address environmental problems is one of the guiding principles of ESD [32], [20]. Reference [15] as cited in [33], states that the solution of environmental problems can be achieved on the basis of cooperation between the actors in the educational process. She justifies it by stating that cooperation, promotion of the values of individual responsibility and co-responsibility are required, but also acceptance of the different way of thinking, since the problems of the environment are amenable to multidimensional solutions based on multidimensional views (p. 6).

\section{5) Critical thinking}

Critical thinking is a mental-emotional function that allows us to analyze, clarify, evaluate, and challenge our perceptions and beliefs, as well as to understand the views of others, in order to reach conclusions, findings, judgments and options for action [34]-[35]. It is, therefore, obvious, how necessary, and important is the application of critical thinking in the life of the individual, that is why it is necessary to cultivate it in school education as well. In this context, the development of critical thinking becomes a central feature of ESD since during the processing of issues related to the environment, critical questions must be analyzed and answered in conflicts of views and interests, and decisions and actions must be taken [21].

\section{6) Cultivation of values}

Values are guiding principles in a person's life. They can influence his attitudes, beliefs, behaviors, and rules, and can be considered as desirable goals for his life [36]. According to [37], the synthesis of ideas, opinions, and concepts, which constitutes the rational perception of the individual about the environment, is reflected in his environmental values. They themselves, as a decisive action aimed at solving environmental problems and achieving sustainable development, propose to create, and through formal and non-formal education, to cultivate proper environmental values.

\section{MethodOLOGY}

\section{A. Method}

A Qualitative Strategy is followed [38], based on the technique of Thematic Analysis (ThA) [39]. The research design is based on the collection of data from parts of the results, discussion, and conclusions of four sample papers, related to the topic.

The research process involves locating and selecting the sample papers. The ThA of the data follows, which is based on seven Sensitizing Concepts which constitute the
Categories of ThA. Relevant results and conclusions are drawn.

The selection of the sample papers was based on how recently the papers were published (all published in 2020) and their character as presentations of real educational applications of Microcontroller systems in environmental sustainability. Four such papers have been identified.

Seven Sensitizing Concepts have been identified, the first six of which are suggested by the relevant literature as requirements of the pedagogical frameworks aimed at achieving the goals of Education for Sustainable Development (ESD). An additional Sensitizing Concept emerged during the course of the research because strong references to its meaning were identified in the sample papers sample. The first six sensitizing concepts are as follows [40] as cited in [16]: (1) Holistic \& systemic thinking, (2) HASS \& STEM Interdisciplinarity \& multidisciplinarity, (3) Constructivist approach to knowledge, (4) Cooperative learning, (5) Critical thinking, (6) Cultivation of values (p. 2). The seventh (7) Sensitizing Concept is Learning Satisfaction.

The research process seems to be characterized by Descriptive and Interpretive Validity since the accurate recording of data on the one hand, and the inclusion of the required information on the other, is by definition the goal and responsibility of the authors of the sample papers [41]. Theoretical Validity is attempted to be ensured by the full reliance on the research of the Sensitizing Concepts, which were produced by the existing theoretical concepts of literature, and Environment Validity is potentially intertwined with the goal of the present paper, which is to investigate the application to the natural, every day, social environment of the classroom [41], [38].

Finally, Credibility also seems to characterize the research as the quality of the data cannot be questioned, since it is data of published scientific papers and therefore the research design, in relation to this data, leads to true and trustworthy findings [42].

The methodological framework of data analysis is based on the identification of Conceptual Patterns which are grouped in Codes, Codes in Categories, and those in the final Theme of analysis. The detection is done with the help of simple office software; the Conceptual Patterns are highlighted in color and recorded in columns per Code in spreadsheet software (Fig. 1). There are 16 Codes, 7 Categories and one Theme (Fig. 2).

\section{B. Researched Papers}

\section{1) Gkiolmas, Dimakos, Chalkidis, and Stoumpa (2020)}

Gkiolmas et al. [4] conducted a case study on "An environmental education project that measures particular matter via a Microcontroller board interface" in a sample of students - members of the school's environmental team, which consisted of seven (7) students. The theme of the group project was the study of particles (PM) in the ambient air of both the school and their home. They explored the impact of a collaborative environmental education project on improving students' behavior, knowledge, and skills. In this project, based on the educational technique of "declining guidance" and "guided discovery", the students at a vocational high school created a robotic device, an artifact, 
based on a Microcontroller board, for measuring the particle pollution of the PM2 and PM10 environment [4]. According to them, the students created, programmed, and used the measuring device, but also carried out an online bibliographic search on the subject of microparticles, which allowed them to gain a deep understanding of the subject.

During the development of the project, in parallel with the construction of the artefact, the students were introduced to other disciplines, mainly related to hovering PM. As discussed in the findings presented in Table 3, the students' overall experience with the construction provided, with the prerequisites for the discovery, on with knowledge related to PM emission, with the problems faced by living organisms who are exposed to environments containing high levels of PM10 and PM2.5, as well as with the ways of countering this problem and conclusively solving it, was judged - generally - as a benficial experience. In addition, most of the students seemed to acquire the basic knowledge and programming skills to utilise the $\mathrm{Ar}$ duino platform. (This can be seen in the meta-cognitive stage, in which they all stated that they considered themselves to be in a position where they could create something similar, with little or no external help.)

Finally, in the socio-sentimental domain, as it stems from Table 2 which comes from their diaries, it can be considered that the procedure was, at the very least, pleasant for the students. "Joy", "satisfaction" and "pride" are not sentiments that one encounters regularly in learners, especially in the Greek schooling system. Nonetheless, these emotions were quite regularly expressed by the participating students. Regarding teamwork, it is considered that the team functioned satisfactorily, especially from the third meeting onwards, and that it had sufficient cohesion and autonomy in decision-making. The students undertook roles, took initiative and, despite the fact that competition between members occurred, worked for the fulfillment of a common aim, realising above all the need for teamaction: "...no matter how much I want to change things, I cannot do this alone...".

It seems that that the teaching intervention was successful in its entirety. Since a plethora of sensors is now available at low cost, similar interventions measuring other environmental parameters, such as different types of pollution in air, soil or water could be designed and implemented in secondary education, with the aim of promoting critical thinking about environmental issues at this stage.

Fig. 1. Detection and labeling of conceptual patterns in the paper of Gkiolmas et al. [4]

\begin{tabular}{|c|c|c|}
\hline Codes (16) & Categories (7) & Themes (1) \\
\hline $\begin{array}{l}\text { Holistic \& systemic } \\
\text { thinking (in general) } \\
\text { Computational Thinking } \\
\text { Problems Solving } \\
\text { Metacognition }\end{array}$ & $\begin{array}{l}\text { Holistic \& systemic } \\
\text { thinking }\end{array}$ & $\begin{array}{l}\text { Ability of utilizing } \\
\text { Microcontroller Systems } \\
\text { in ESD }\end{array}$ \\
\hline $\begin{array}{l}\text { Interdisciplinarity \& } \\
\text { multidisciplinarity STEM } \\
\text { Interdisciplinarity \& } \\
\text { multidisciplinarity HASS } \\
\text { (in general) }\end{array}$ & \multirow[t]{2}{*}{$\begin{array}{l}\text { HASS\&STEM } \\
\text { Interdisciplinarity \& } \\
\text { multidisciplinarity }\end{array}$} & \\
\hline $\begin{array}{l}\text { Environmental \& } \\
\text { Sustainability Concepts } \\
\text { (especially) }\end{array}$ & & \\
\hline $\begin{array}{l}\text { Constructivism (in general) } \\
\text { Contextual Learning } \\
\text { Discovery learning } \\
\text { Experiential Learning }\end{array}$ & $\begin{array}{l}\text { Constructivist } \\
\text { approach to } \\
\text { knowledge }\end{array}$ & \\
\hline $\begin{array}{l}\text { Cooperative learning (in } \\
\text { general) }\end{array}$ & Cooperative learning & \\
\hline $\begin{array}{l}\text { Critical thinking (in } \\
\text { general) }\end{array}$ & Critical thinking & \\
\hline $\begin{array}{l}\text { Cultivation of values (in } \\
\text { general) }\end{array}$ & \multirow[t]{2}{*}{ Cultivation of values } & \\
\hline $\begin{array}{l}\text { Cultivation of } \\
\text { environmental } \\
\text { sustainability values }\end{array}$ & & \\
\hline $\begin{array}{l}\text { Learning Satisfaction (in } \\
\text { general) }\end{array}$ & Learning Satisfaction & \\
\hline
\end{tabular}

Fig. 2. Thematic Analysis Map: Themes, Categories, Codes \& Marking Colors Index.

\section{2) Savelides and Savelidi (2020)}

Savelides and Savelidi [5] in their work - case study - on "The Intelligent Wall". The Electrical Analogy as an Educational Technique in the Context of HASS \& STEM \& Contextual Learning" designed, developed and evaluated a Prototype of an interdisciplinary educational scenario, in which the didactical technique of Analogs is applied, in which the Electric Analog is utilized with a Microcontroller Board as the mail educational tool. The Scenario and especially the completeness of its interdisciplinarity were evaluated by 11 teachers of the course Research Project in Technology. The scenario didactically covers scientific areas of HASS \& STEM [27]. According to Savelides and Savelidi in the scenario, students are asked to create their own teaching tool, a Model, the "Intelligent Wall". First the Model is created digitally and then as material. Then, students experiment with it, mostly with the help of ICTs. They experiment with the composition of different walls, digitally calculating heat loss and investigating how masonry affects carbon dioxide emissions, the economy, and the environment itself to solve related interdisciplinary problems.

\section{3) Lu, Hong, Chen, and Ma (2020)}

Lu et al. [3] conducted a case study with the subject "Elementary school students learn Microcontroller board programming to assemble sensory-controlled works" which was based on a qualitative and quantitative strategy, involving 54 students from the fifth and sixth grade of elementary school in Taiwan as a research sample. The study aimed to design an interdisciplinary curriculum for science, technology, engineering, and mathematics (STEM) for elementary school students in order to cultivate their literacy in STEM. They report that in a series of courses of environmental and ecological interest, teachers taught students the operation of green buildings or the special habits of various animals. They also taught how to choose the right background and materials for assembling green buildings or animals. Finally, the students were taught the programming of the Microcontroller board for the assembly of green buildings or animals controlled by sensors, so that they can respond accordingly, such as opening and closing windows in the green buiding.

\section{4) Alò, Castillo, Marín Vial, and Samaniego (2020)}

Alò et al. [43] conducted a mixed strategy research (quantitative and qualitative) with the participation of 115 seventh graders from five public, underprivileged schools in southern Chile. The title of the research was "Low-cost emerging technologies as a tool to support informal environmental education in children from vulnerable public schools of southern Chile". Students participated in workshops based on Microcontroller board technology to address current environmental problems caused by global change and humanization [43]. The intervention was based on the observation of a positive attitude and interest in the subjects of science, as well as the desire to do experiments and practical work. They state that this gave students the opportunity to experience the development of a small environmental monitoring station with Microcontroller board technology as an activity, with the teaching technique of the project (collaborative teaching) and the application of 
the scientific method.

\section{RESUlts AND DisCUSSION}

The results of ThA of the four papers, per Category, are as follows:

\section{1) Category: Holistic \& systemic thinking}

In all four papers, conceptual patterns were found which relate to the Codes of this Category. For example [5] states that using Microcontrollers, "It is possible to develop realworld problem solving, especially based on models and techniques of Computational Thinking" explicitly noting Computational Thinking approaches and Problem Solving. A more general reference to holistic \& systemic thinking is made by [43]: "The analysis applied to the open-ended questions allowed us to make connections between the different parts of the information collected and interpret it in more depth. We organized the codes through relationship networks that graphically represented possible structures or systems of relationships between codes... This exercise allowed us to synthesize the main concepts and their connections....". It is therefore concluded that as new teaching and learning tools, Microcontroller systems are likely to have a greater and long-lasting educational impact on students by developing Holistic \& Systematic thinking skills through holistic problem solving [43]. Based on these, there can be educational applications that promote students' metacognition [3] and their holistic and systemic thinking in general [5].

\section{2) Category: HASS \& STEM Interdisciplinarity \&} multidisciplinarity

In all four papers, conceptual patterns were found, which concerned interdisciplinarity \& multidisciplinarity, something considered natural since the papers were selected based on the composition of a STEM object (Microcontroller) with a HASS object (environmental sustainability). In addition, [3] reports: "Arduino programming to assemble sensory-controlled works could enhance the STEM literacy of elementary school students: the subject survey course teaching and the results of statistical analysis of the STEM literacy test showed that elementary school students who implemented subject survey learning were taught in cross-disciplinary fields". It seems that Microcontroller systems can be educational tools that can combine electromechanical technology, information technology and other sciences. Thus, the combination of the above two applications (in the environment and education) concludes that Microcontroller board systems can be applied in education for the environment and Sustainability [1]. The application of Microcontroller board programming for the assembly of controlled sensory projects, such as environmentally intelligent constructions, could improve literacy in STEM but also the Interdisciplinarity knowledge and Metacognition of students [3]. In general, it seems that Microcontroller board systems can be used in the school laboratory, in research courses and to approach interdisciplinarily the fields of HASS \& STEM and therefore ESD [5].

\section{3) Category: Constructivist approach to knowledge}

In all papers, conceptual patterns were identified, which correspond to the Codes of this Category, which is also considered natural since all four works aim at the use of a state-of-the-art educational tool through which they aim at building new deep knowledge in their students. Characteristically, [4] reports: "The recording of the development over time of an Environmental Education project based on the principles of Constructionism. The main idea of the project was the design of an 'artefact' -a measurement tool for air pollutants, based on the Arduino platform". They themselves, referring to Discovery Learning, state "... which they would then use to investigate the quality of the air they breathe" (pp. 100027). And they continue by saying "During the second meeting (two teaching hours), students from both groups searched the world wide web for information regarding hardware construction and software development, in order to build their Arduino-based measuring device" (pp. 100027). Also, [5] states: "[it is] possible to use [the Microcontroller board], as it meets the principles of Contextual Learning, since it can be the start of the development of framed strategies such as associating a new idea with something familiar, encouraging exploration, discovery, or invention, use of concepts in realistic and relevant exercises" (p. 244). Thus, we can agree that it is possible to use Microcontroller board systems in environmental education in the context of Constructivism, Contextual and Discovery learning and Computational Thinking [5].

\section{4) Category: Cooperative learning}

In each paper, conceptual patterns are identified, which highlight the use of collaborative educational techniques. Indicatively, [3] reports: "The collaborative teachers and each group of students form a close synergy relationship, and work together to complete the teaching activities, giving full play to the team spirit of teaching and learning" ( $\mathrm{p}$. 265). It therefore seems that Microcontroller systems can contribute to faster learning, within Collaborative and Experiential frameworks [43]-[45].

\section{5) Category: Critical thinking}

The goal and achievement of the development of critical thinking in students, is implied or expressed directly in all four papers by a significant number of conceptual patterns. Indicatively, [43] reports: "These new teaching and learning tools will likely have a greater and long-lasting educational impact on students, promoting faster learning, problem solving ability and foster their critical thinking skills, among other benefits." (p. 651). Thus, it can be concluded that educational interventions, based on Microcontroller systems, which measure environmental parameters could be designed and implemented in education, with the aim of promoting critical thinking on environmental issues [4], to promote students' skills in solving problems, and advance their critical thinking skills [43].

\section{6) Category: Cultivation of values}

There is a small number of conceptual patterns that relate to the cultivation of values. In three of the four papers, the utilization of these systems with the aim of general cultivation of values is implied, and in two, patterns are 
identified which imply the possibility of cultivating environmental values. Regarding this possibility, in its general effect, [43] reports: "Furthermore, the development of positive attitudes towards science and technology can motivate young people interested in science education and science related careers" (p. 651). More specifically, regarding the cultivation of environmental values, [4] reports "... the use of Arduino-based measuring devices raised high school students' awareness and curiosity towards the environmental factors under investigation..." (p. 100027). In the same vein [5] reports: "The criteria upon which the Design of a Prototype Scenario [with a Microcontroller Board tool] was designed and evaluated, were based... in the students' development of knowledge, skills, and perceptions, regarding...Social Responsibility, ... Sustainability - environment [and others]" (p. 236). However, it seems (perhaps not very clearly) that the appropriately adapted application of Microcontrollers in educational scenarios can influence the change of attitudes and behaviors through the cultivation of values.

\section{7) Category: Learning Satisfaction}

Conceptual patterns have been identified, whose examination suggests that experiential applications with a Microcontroller as an educational tool, in addition to scientific knowledge and metacognition, give feelings of satisfaction, self-efficacy and enthusiasm to students and therefore contribute to the development of environmental awareness in a pleasant experiential way [4]. Characteristically, it states: "Finally, in the sociosentimental domain..... it can be considered that the procedure was, at the very least, pleasant for the students. "Joy", "satisfaction" and "pride" are not sentiments that one encounters regularly in learners, especially in the Greek schooling system. " (p. 100027). In the same vein [43] reports: "Engaging activities can provide learning in an entertaining way, enhancing students' inclination in learning science." (p. 648).

\section{CONCLUSION}

The aim of this paper is to answer the research question whether the proper use of Microcontroller board systems, as educational tools, can help achieve the goals of Education for Sustainable Development (ESD). To answer the question, a quality strategy meta-survey of four recently published works on the subject was conducted. The Thematic Analysis (ThA) technique was used. The results showed that the appropriate adaptation to the educational process of the Microcontroller Board Systems can sufficiently help achieve the goals of Education for Sustainable Development (ESD). In order to achieve these goals in a pedagogical context, the Microcontroller system, can be adapted in such a way as to serve the approaches of holistic \& systemic thinking, Interdisciplinarity \& Multidisciplinarity HASS \& STEM, Constructivist approach to knowledge, Cooperative learning, Critical thinking the Cultivation of values and the Learning Satisfaction. And the adaptation to these educational and pedagogical approaches seems to be possible.

In addition, the results showed that Microcontroller systems, as educational tools, can support contextual and discovery learning, computational thinking and problemsolving ability through experimental learning environments. In addition, their integration into the educational process seems to give students feelings of satisfaction, self-efficacy, and enthusiasm, and therefore contributes to the development of environmental awareness in a pleasant experiential way.

\section{NOTES}

Author Contributions: Conceptualization, M.S., S.S., E.G., G.P., R.F. and H.D.; methodology, M.S. and S.S.; formal analysis, M.S.; investigation, M.S. and S.S.; thematic meta-analysis, M.S. and S.S; resources, E.G., G.P., R.F. and H.D.; data curation, M.S., E.G., G.P. and R.F.; engineering data analysis, M.S.; writing - original draft preparation, M.S., E.G., G.P. and R.F.; writing-review and editing, S.S. and H.D.; supervision, S.S. and H.D. All authors have read and agreed to the published version of the manuscript.

\section{REFERENCES}

[1] Kondaveeti H. K., Kumaravelu N. K., Vanambathina S. D., Mathe S. E., \& Vappangi S. A systematic literature review on prototyping with Microcontroller board: Applications, challenges, advantages, and limitations, Computer Science Review, 2021;40:100364,.

[2] Banks T., Wallace S., Glazewski K., Sedas M., \& McKay C. What a Middle School learned about Environmental Sustainability, Sustainable Food Systems, Microcontroller board, and Aquaponic Farming. Presented at the 6th Annual FabLearn 2016 Conference on Creativity and Making in Education. Stanford, CA: Stanford University, 2016.

[3] Lu C. C., Hong J. C., Chen F. F., \& Ma S. Y. Elementary school students learn Microcontroller board programming to assemble sensory-controlled works. Int. J. Inf. Educ. Technol, 2020;10(4):265270 .

[4] Gkiolmas A., Dimakos C., Chalkidis A., \& Stoumpa A. An environmental education project that measures particulate matter via an Microcontroller board interface. Sustainable Futures, 2020;2:100027.

[5] Savelides S. \& Savelidi M. S. The Intelligent Wall. The Electrical Analogy as an Educational Technique in the Context of HASS\&STEM \& Contextual Learning. In A. Alexandrís, P. Vlámos, Ch. Douligéris \& V. S. Belesiótis (Epim.), Proceedings of the 12th Conference on Informatics in Education (CIE 2020), pp. 231-245, ISBN: 978-960-578-072-2. (in Greek), Peiraias: Tmíma Pliroforikís tou Panepistimíou Peiraiós, Tmíma Pliroforikís tou Ioníou Panepistimíou, Ellinikí Etaireía Epistimónon kai Epangelmatión Pliroforikís kai Epikoinonión, 17-18 Oktovríou, 2020.

[6] Cordova-Huaman A. V., Jauja-Ccana V. R., \& La Rosa-Toro A. Lowcost smartphone-controlled potentiostat based on Microcontroller board for teaching electrochemistry fundamentals and applications. Heliyon, 2021;7(2):e06259.

[7] Florea A. Teaching The Microprocessors Systems Focused on Societal Challenges: Designing of Performant Cache Replacement Algorithms as Green Information Technology (IT) Solution. Journal of Digital Information Management, 2017;12(2).

[8] Raptis A. \& Rapti A. Máthisi kai didaskalia stin epochi tis pliroforías. A' tómos. Athína. (in Greek), 2013.

[9] Wing J. M. Computational thinking and thinking about computing Philosophical Transactions of the Royal Society A: Mathematical, Physical and Engineering Sciences, 2008;366(1881):3717-3725.

[10] Psycharis S., Kotzampasaki E., \& Kalovrektis K. Ypologistikí Sképsi, Epistimología ton Michanikón kai Ypologistikí Paidagogikí: Mia prótasi eisagogís tou STEM stin ekpaídefsi. Ekpaídefsi \& Epistímes, 1, pp. 1-11. (in Greek), 2018.

[11] Balım A. G. The Effects of Discovery Learning on Students' Success and Inquiry Learning Skills. Eurasian Journal of Educational Survey (EJER), 2009;35. 
[12] Chang I-Y. and Chang W-Y. The effect of student learning motivation on learning satisfaction. International Journal of Organizational Innovation, 2012;4.3.

[13] UNESCO. Issues and trends in Education for Sustainable Development. Paris: UNESCO, 2018.

[14] Agbedahin A. V. Sustainable development, Education for Sustainable Development, and the 2030 Agenda for Sustainable Development: Emergence, efficacy, eminence, and future. Sustainable Development, 2019;27(4):669-680

[15] Dimitriou A., Perivallontiki Ekpaidefsi: Perivállon, Aeiforia. Theoritikés kai paidagogikés prosengiseis, Thessaloníki: Epíkentro, (in Greek), 2009.

[16] Ragkou P. Ekpaídefsi gia to perivállon kai tin Aeifóro Anáptyxi: Vasikés énnoies. ETRES, 2016. (2016-1-FR01-KA202-023941). Retrived form https://etreserasmus.eu (in Greek).

[17] Fragou E. Education for the Environment and Sustainability: Conceptual approaches to teaching adopted by teachers (No. GRI2017-19999). Aristotel University of Thessaloniki, 2017, pp.26.

[18] Flogaiti E. Olistikótita, diepistimonikótita, systimiki sképsi, Panepistímio Aigaíou, (in Greek), 2012, pp. 2.

[19] Ragkou P. Didactic of Environmental Education, School of Forestry and Natural Environment, Aristotle University of Thessaloniki, 2019.

[20] UNESCO. Intergovernmental Conference on Environmental Education, Tbilissi (USSR, 14-26 October 1977), Final Report, Paris: UNESCO, 1978

[21] Flogaiti E. Ekpaidefsi gia to perivállon kai tin aeiforia, Athína: Pedío, (in Greek), 2011b, pp.159.

[22] Flogaiti E. Perivallontikí Ekpaídefsi, Athína: Pedío, (in Greek), $2011 \mathrm{a}$.

[23] Kalaitzidis D. \& Ouzounis K. Perivallontiki Ekpaídefsi, Xanthi Spanidi, (in Greek), 2000.

[24] Zoukis N. I dia-epistimonikótita pou metafrástike os «diathematikótita», i simasía tis evaísthitis exártisis apó tis archikés synthíkes kai i néa prooptikí. Thémata Eidikís Agogis. Téfchos, 2008;41(42):74-82, 80-89. (in Greek).

[25] Georgousis E., Savelides S. \& Drinia H. Interdisciplinary Approach Survey of STEM\&HASS Educational Objects in Confronting Complex Environmental Problems, in Proceedings of the 8th Conference on Environmental Education for Sustainability in the Age of Climate Change, Patra, Greece, 11-13 September 2020.

[26] Georgousis E., Savelides S., Mosios S., Holokolos M.-V. \& Drinia H. The Need for Geoethical Awareness: The Importance of Geoenvironmental Education in Geoheritage Understanding in the Case of Meteora Geomorphes, Greece. Sustainability, 2021;13(12):6626. doi: https://doi.org/10.3390/su13126626.

[27] Savelides S. C., Fasouraki R., Georgousis E., Kolokotroni K. and Savelidi M. S. Interdisciplinary Educational Approach STEM and HASS Knowledge Fields Using ICTs Support. Case of an Application for a Pilot Experiment. EJERS: European Journal of Engineering Survey and Science, (CIE), 2020;33-42. doi https://doi.org/10.24018/ejers.2020.0.CIE.1797.

[28] Steffe L. P. \& Gale J. E. (Eds.), Constructivism in education, Psychology Press, 1995.

[29] Liarakou G. I chartográfisi ennoión. University of the Aegean. (in Greek), 2012.

[30] Ausubel D.P. Educational Psychology: A Cognitive View, New York: Holt, Rinehart \& Winston, 1968

[31] Felder, R. M., \& Brent, R., "Cooperative learning", Active learning. Models from the analytical sciences, 970, pp.34-53, 2007.

[32] UNESCO. The International workshop on environmental education (Belgrade, Yugoslavia, 13-22 Oct. 1975). Final report. Paris: UNESCO, 1976.

[33] Stamatis P., Pazaropoulos S., Mastoris M. \& Theodosiadou P. "Didaktikes proseggiseis kai paidagogikes methodoi stin Perivallondiki Ekpaidefsi", in: Proceedings of 5th Conference of Hellenic Institute of Applied Pedagogy \& Education (HEL. I. A. P. ED.), Mathaino pos na mathaino, May 2010, retrieved from http://www.elliepek.gr (in Greek).

[34] Sauvé L. Pour une éducation relative à l'environnement. Montréal: Guérin, Paris: Eska, 1994, pp.135.

[35] Matsagouras H. Theoría kai práxi tis didaskalías. Stratigikés didaskalias. I kritiki sképsi sti didaktiki práxi, Athens: Gutenberg, (in Greek), 2000.

[36] Steg L., \& De Groot J. I. M. Environmental values, in: The Oxford handbook of environmental and conservation psychology, S. Clayton (Ed.), Oxford University Press, 2012, pp. 81-92. https://doi.org/10.1093/oxfordhb/9780199733026.013.0005.

[37] Chuanhui Z. \& Hanwei Z. Cultivation of environmental values for university students under strategic background of environmental informationization. Energy Procedia, 2011;5:945-951
[38] Bryman A. Social survey methods, New York: Oxford University Press, 2012.

[39] Issari P. \& Pourkos M. Poiotiki Methodología Erevnas. Athens: Sýndesmos Ellinikón Akadimaïkón Vivliothikón, 2015. Retrieved from https://repository.kallipos.gr/handle/11419/5826. (in Greek).

[40] Dimitriou A. Perivallontiki Ekpaídefsi: Perivállon, Aeiforía Theoritikés kai paidagogikés prosengiseis, Ekdóseis Epíkentro (No. IKEEBOOK-2020-133), (in Greek), 2005.

[41] Maxwell J. Understanding and validity in qualitative research. Harvard educational review, 1992;62(3):279-301.

[42] Symeou, L., "Enkyrótita kai axiopistía stin poiotikí erevna: To parádeigma mías erevnas gia ti synergasía scholeíou-oikogéneias", in H. Phtiaka, A. Gagatsis, I. Elia, \& M. Modestou (Epim.), Praktika apó to 9o Synédrio Paidagogikís Etaireías Kýprou, (pp. 1055-1064) Lefkosía: Paidagogikí Etaireía Kýprou. (in Greek), 2-3 June 2006.

[43] Alò D., Castillo A., Marín Vial P., \& Samaniego H. Low-cos emerging technologies as a tool to support informal environmental education in children from vulnerable public schools of southern Chile. International Journal of Science Education, 2020;42(4):635655

[44] Clark L., Majumdar S., Bhattacharjee J., \& Hanks A. C. Creating an atmosphere for STEM literacy in the rural South through studentcollected Weather data. Journal of Geoscience Education 2015;63(2):105-115.

[45] Tseng K. H., Chang C. C., Lou S. J., \& Chen W. P. Attitudes towards science, technology, engineering and mathematics (STEM) in a project-based learning (PjBL) environment", International Journal of Technology and Design Education, 2013;23(1):87-102.

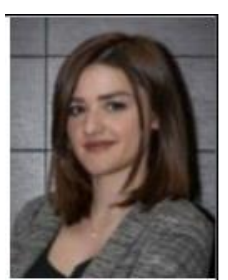

Maria S. Savelidi was born in Volos, Greece in 1994. She has a Bachelor's in Organization and Business Administration from University of Macedonia, Thessaloniki, Greece. She speaks English, French, Italian and Dutch. She has participated in two international innovation competitions. She is currently an MSc Business Engineering student in the University of Ghent, in the field of Finance. She has carried out publications on ICTs, Innovation and Educational Management.

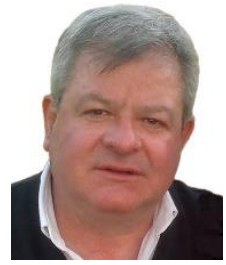

Socrates C. Savelides was born in Volos, Greece in 1963. He was the Director of Secondary Education of Magnesia-Greece for the last five years. The Directorate of Magnesia includes seventy-four secondary schools. He is a secondary teache specialized on Mechanical Engineering. Dr Savelides received his Doctorate in Crisis Management in Secondary Schools in 2011 from the Greek Open University as first MA in Total Quality Management (Quality Assurance) in 2005, and his second MA in Sustainability and Environmental Education in 2021 from the University of Thessaly. He has been a Secondary school Principal or an Assistant Principal for over fifteen years and Principal of the Pedagogical and Technological Education Faculty - Volos branch, for two years. He has carried out publications on ICTs, Crisis Management Educational Management, Total Quality Management and Environmental Sustainability.

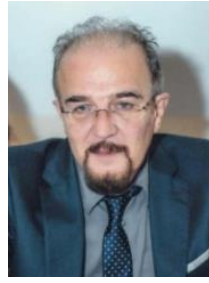

Efthymios Georgousis was born in Volos, Greece. He is currently working as a Junior High School teacher. He holds a BA Honors degree in Theology from the Faculty of Theology of Aristotle University of Thessaloniki (AUTh), a Master's Degree (MA) with specialization in Biblical Studies and Study of Religion from the same University (AUTh) (1993) and a Master's degree in Environmental Management Strategies with specialization in Didactics of Environmental Management (MSc) from the Faculty of Geology and Geoenvironment of the National and Kapodistrian University of Athens (UoA) (2019). Moreover, he has specialized in Pedagogical Counseling (Pädagogische Beratung) at Akademie für Lehrerfortbildung und Personalführung Dillingen in München (2003 to 2005) and in Counseling and Guidance in 2016 at the School of Pedagogical and Technological Education (ASPETE) - Volos branchGreece. He is currently a $\mathrm{PhD}$ candidate at the Faculty of Geology and Geoenvironment (UoA) 


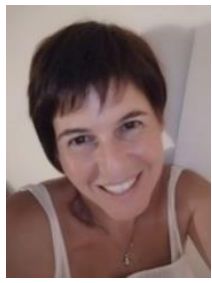

Georgia Papadopoulou was born in Thessaloniki, Greece. She holds a Diplom in Pedagogic from the Pedagogical Department for Primary Education of Aristotle University of Thessaloniki (AUTh) and a Magister Artium M.A. in the field of Special Education for Language impaired children together with School Psychology and Children and Adolescent Psychiatry as secondary fields from the L.M.U. University of Munich, Germany. She speaks English and German. She is currently working as a Special Education Teacher in an Integration Class of a mainstream school in Thessaloniki, Greece and participating in a Master Degree Program in the field of Environmental Education for Sustainability at University of Thessaly (UTh), Volos.

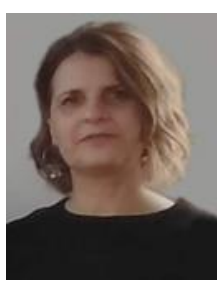

Rigo Fasouraki was born in Volos, Greece. She is the Head of Educational Departemen of Secondary Education of Magnesia-Greece for the last three years. She is a secondary teacher specialized on Civil Engineering. She holds a Masters Degree in Education Administration from Aegean University (2008). Moreover, he has specialized in Pedagogical Counseling of the National and Kapodistrian University of Athens (UoA) (2012) and in Counseling and Guidance in 2009 at the School of Pedagogical and Technological Education (ASPETE-ATHENS).

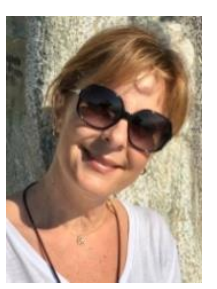

Hara Drinia is a full Professor of Palaeoecology Sedimentology at the Department of Geology and Geoenvironment at the National and Kapodistrian University of Athens. Her main research interests are Sedimentology, Palaeoecology, Stratigraphy, Marine Ecosystems, Environmental Education, Geoscience Teaching, Geoheritage, Geoconservation. Prof. Hara Drinia has published a large number of scientific papers in the field of palaeontology and stratigraphy, with particular emphasis on palaeoecology and palaeogeography, geobiology, reconstruction of sedimentary environments, sedimentary facies analysis, sequence stratigraphy. She has been actively involved in many international scientific conferences and in regional, national, and international meetings. She has a strong record of participating in research programs and initiatives and has been the Principal Investigator of several research projects. Regarding her wider contribution to the geological community, it is worth noting that Prof. Drinia is an active member of eight geosciences committees and has been a member of the organizing committee of eight international and national geological conferences. She is also actively involved in Socrates / Erasmus educational exchange programs in Switzerland, Germany, and Italy. 